Roy, C. L. and P. L. Coy. 2021. Lek attendance and disturbance at viewing blinds in a small, declining Sharp-tailed Grouse (Tympanuchus phasianellus) population. Avian Conservation and Ecology 16(2):25. https://doi.org/10.5751/ACE-01986-160225

Copyright (C) 2021 by the author(s). Published here under license by the Resilience Alliance.

Research Paper

\title{
Lek attendance and disturbance at viewing blinds in a small, declining Sharp-tailed Grouse (Tympanuchus phasianellus) population
}

Charlotte L. Roy ${ }^{1}$ and Pamela L. Coy ${ }^{1}$

${ }^{1}$ Minnesota Department of Natural Resources

ABSTRACT. Conservation agencies use viewing blinds at prairie grouse leks as an outreach tool to engage the public. However, in declining bird populations, disturbance at viewing blinds associated with observer arrivals and departures may exacerbate inconsistencies in lek attendance. We studied observer arrivals and departures at public viewing blinds placed at Sharp-tailed Grouse (Tympanuchus phasianellus) lekking areas using trail cameras. We also conducted an experiment to simulate observers arriving late or leaving early from viewing blinds and compared Sharp-tailed Grouse attendance and return times at these treatment leks to the same leks when observers arrived in the dark and left late in the morning as a control. Observers at public blinds arrived later and left earlier than manager-recommended guidelines for utilizing blinds. In experiments, periods during which no birds were in attendance at leks were longer after observer arrivals later in the morning than at controls. However, the return times of returning birds were similar at leks disturbed early, late, and at controls, although fewer birds returned to leks disturbed later in the morning compared to those disturbed early. Return times after observer arrivals were longer than after raptor disturbance and after observer movements within the blind. We did not observe mating or male-female pairs leaving leks together during disturbance treatments but we did at similar times during control observations, despite almost half the time spent at controls. We suggest that disturbances early, when females are more likely to be in attendance, are more likely to disrupt mating than disturbances that occur later, despite fewer males returning to leks disturbed later in the morning. We suggest that managers consider the impacts of human disturbance at viewing blinds in declining populations and potential mating losses that might occur at leks with inconsistent attendance.

\section{Fréquentation des leks et dérangement aux postes d'observation chez une petite population de Tétras à queue fine (Tympanuchus phasianellus) en baisse}

RÉSUMÉ. Les organismes de conservation utilisent les postes d'observation de leks de tétras des prairies comme outil de sensibilisation du public. Cependant, chez les populations d'oiseaux en baisse, le dérangement engendré par les arrivées et les départs d'observateurs aux postes d'observation peut exacerber l'irrégularité de la fréquentation des leks. Nous avons étudié les arrivées et les départs d'observateurs aux postes d'observation publics placés près de leks du Tétras à queue fine (Tympanuchus phasianellus) à l'aide de caméras. Nous avons également mené une expérience pour simuler l'arrivée tardive ou le départ précoce d'observateurs aux postes d'observation et avons comparé les temps de présence et de retour des Tétras à queue fine dans ces postes-traitements aux mêmes postes lorsque les observateurs arrivaient dans l'obscurité et partaient tard le matin comme témoin. Les observateurs aux postes publics sont arrivés plus tard et sont partis plus tôt que ce qui est recommandé par les gestionnaires. Pour les expériences, les périodes pendant lesquelles aucun oiseau n'était présent dans les leks étaient plus longues après l'arrivée des observateurs plus tard dans la matinée que pour les témoins. Toutefois, le temps de retour des oiseaux était similaire dans les leks ayant été dérangés tôt ou tard, et pour les témoins, bien que moins d'oiseaux soient revenus dans les leks ayant été dérangés plus tard dans la matinée que dans ceux ayant été dérangés tôt. Le temps de retour après l'arrivée d'observateurs était plus long qu'après un dérangement par des rapaces ou suite à des mouvements d'observateurs à l'intérieur d'un poste. Nous n'avons pas observé d'accouplement ou de paires mâle-femelle quittant ensemble les leks lors des traitements avec dérangement, mais nous en avons observé lors des observations-témoins, malgré que nous ayons passé près de la moitié du temps aux témoins. Nous croyons que le dérangement tôt le matin, lorsque les femelles sont plus sujettes d'être présentes, est plus susceptible de perturber l'accouplement que le dérangement qui survient plus tard, malgré le fait que moins de mâles retournent dans les leks ayant été dérangés plus tard dans la matinée. Les gestionnaires devraient prendre en compte les impacts du dérangement humain aux postes d'observation chez les populations en baisse et les occasions d'accouplement manquées qui pourraient advenir dans les leks dont la fréquentation est irrégulière.

Key Words: dancing grounds; human disturbance; lek; Sharp-tailed Grouse; Tympanuchus phasianellus; viewing blinds 


\section{INTRODUCTION}

Sharp-tailed Grouse (Tympanuchus phasianellus) populations have faced severe reductions to their historic range within the Great Lakes region (Miller and Graul 1980) and have continued to decline over the last few decades (Maples and Soulliere 1996, Hanson 2021, Roy 2021). Public engagement and support for habitat management and other conservation practices becomes increasingly important as more financial resources and political support become necessary to reverse declining population trends. Conservation agencies use viewing blinds for outreach and education to generate an appreciation for prairie grouse and their life history (Oberbillig 2011). However, in declining Sharp-tailed Grouse populations, lek sizes are often small and unstable (Roy 2021), which may reduce the usefulness of viewing blinds as a conservation tool; viewing blinds are expected to give a reliable viewing experience (Oberbillig 2011).

Birds in declining populations may become less tolerant to disturbances at leks, the consequences of disturbances at leks may last longer, or repeated disturbances might cause birds to flush at longer distances (Smit and Visser 1993, Laursen et al. 2005, Stankowich and Blumstein 2005, Baines and Richardson 2007, Thiel et al. 2007). Flushing distance, or escape distance, likely reflects trade-offs between perceived risk of predation, the cost of vigilance and escape, as well as the cost of missed opportunities to mate, maintain a territory, and forage (Ydenberg and Dill 1986, Laursen et al. 2005, Stankowich and Blumstein 2005). Other studies have found increasing wariness with repeated disturbance (Baines and Richardson 2007, Thiel et al. 2007, see review by Storch 2013). Therefore, human activity at viewing blinds, which might cause repeated disturbances, may reduce lek attendance and exacerbate obstacles to successful reproduction at leks in populations already facing challenges to persistence.

Male Sharp-tailed Grouse are tolerant to many types of disturbance at leks (Baydack 1986, Baydack and Hein 1987). Although males often flush in response to human presence on leks, males return to display activity shortly after humans depart. Female Sharp-tailed Grouse, however, are more easily displaced from leks by various types of disturbance (e.g., human presence, vehicles, or dogs) and were not observed at disturbed leks (Baydack 1986, Baydack and Hein 1987). Baydack and Hein (1987) suggested that human and other types of disturbance at leks may lower production by delaying mate selection and result in more late nests, which tend to be less successful than early nests (Robel 1970). They went on to suggest that some disturbed leks may become reproductively inactive despite continued male display activity, and that over several years this may produce population declines. Therefore, understanding how disturbance related to human attendance at viewing blinds might impact lek attendance, especially in declining populations, is needed to evaluate the utility of viewing blinds as a conservation outreach tool. If human disturbance of Sharp-tailed Grouse at blinds is detrimental in declining populations, wildlife managers may choose to use other conservation tools that have less potential risk to successful reproduction.

We set out to determine whether viewing blinds may have a negative impact on lek attendance in a declining population of Sharp-tailed Grouse in Minnesota, United States (Roy 2019). We hypothesized that observers at blinds would reduce lek attendance and that return times after observer disturbances would be longer than after disturbance by predators. We conducted experiments to simulate the impact of observers arriving at blinds later than the time recommended by wildlife managers and the impact of observers disturbing birds later in the morning, such as when observers leave blinds before birds depart leks each day. We compared lek attendance after experimental disturbance to that at control sites where observers arrived in the dark and departed after birds had left for the morning. We also measured return times after disturbances caused by observers and compared them to return times in response to disturbance by raptors. We interpreted our experimental results in the context of actual public visitation at viewing blinds. In a complementary descriptive study, we examined whether visitors complied with recommended guidelines provided by wildlife managers for arrival to and departure from public viewing blinds and the potential implications of deviations from guidelines. Finally, we documented how lek attendance varied in a declining population. Descriptions of erratic attendance at leks has been provided in some accounts of declining populations (Johnsgard 2002), but we were unaware of any quantification of this phenomenon.

\section{STUDY AREA}

Sharp-tailed Grouse use brushlands in Minnesota landscapes with more native grass/sedge, lowland hardwoods, and conifer bog and less upland forest and conifer regeneration than random brushland sites (Hanowski et al. 2000). Leks for the viewing blind disturbance experiment were in the east-central part of Minnesota Sharp-tailed Grouse range (Fig. 1) where the number of leks counted has declined by $>50 \%$ since 2010 , lek size has declined almost 30\% over the same period (Roy 2019), and analysis of genetic material has indicated evidence of a recent population bottleneck (Roy and Gregory 2019). Average lek size in this region was 7.3 birds in 2018 and 7.2 birds in 2019 (Roy 2018, 2019).

For the descriptive study, we included two public viewing blinds in east-central Minnesota where the experimental study was focused and two in northwestern Minnesota (Fig. 1). In the northwest, the number of leks counted has declined for the last four years but has been within the usual range of fluctuations, and lek size has been stable over the same period with 9.8 birds in 2018 and 11.0 birds in 2019 (Roy 2021). These viewing blinds were the only blinds managed by the Minnesota Department of Natural Resources during the study. However, five additional blinds had been previously available for public use before grouse numbers dwindled (J. Provost, personal communication).

\section{METHODS}

\section{Experimental study}

We located lekking areas where male Sharp-tailed Grouse assembled in the morning. We delineated the spatial area used by the birds after they departed for the morning, as indicated by fecal pellets, with survey flags on wire posts, and then staked a portable blind $3 \mathrm{~m}$ from the outer edge of the flagged area at the start of the experiment, and then removed the flags. Early in the study we tried placing blinds $15 \mathrm{~m}$ and $30 \mathrm{~m}$ from the outer edge of the pellets, but we could not see the birds clearly through vegetation 
Fig. 1. Sharp-tailed Grouse (Tympanuchus phasianellus) leks in the experimental and observational studies of viewing blinds in Minnesota, USA during 2018-2019. Lek numbers 1-16 coincide with those in the experimental study (Table 1). Leks 17-20 were those used in the observational study of public viewing blinds (Table 2).

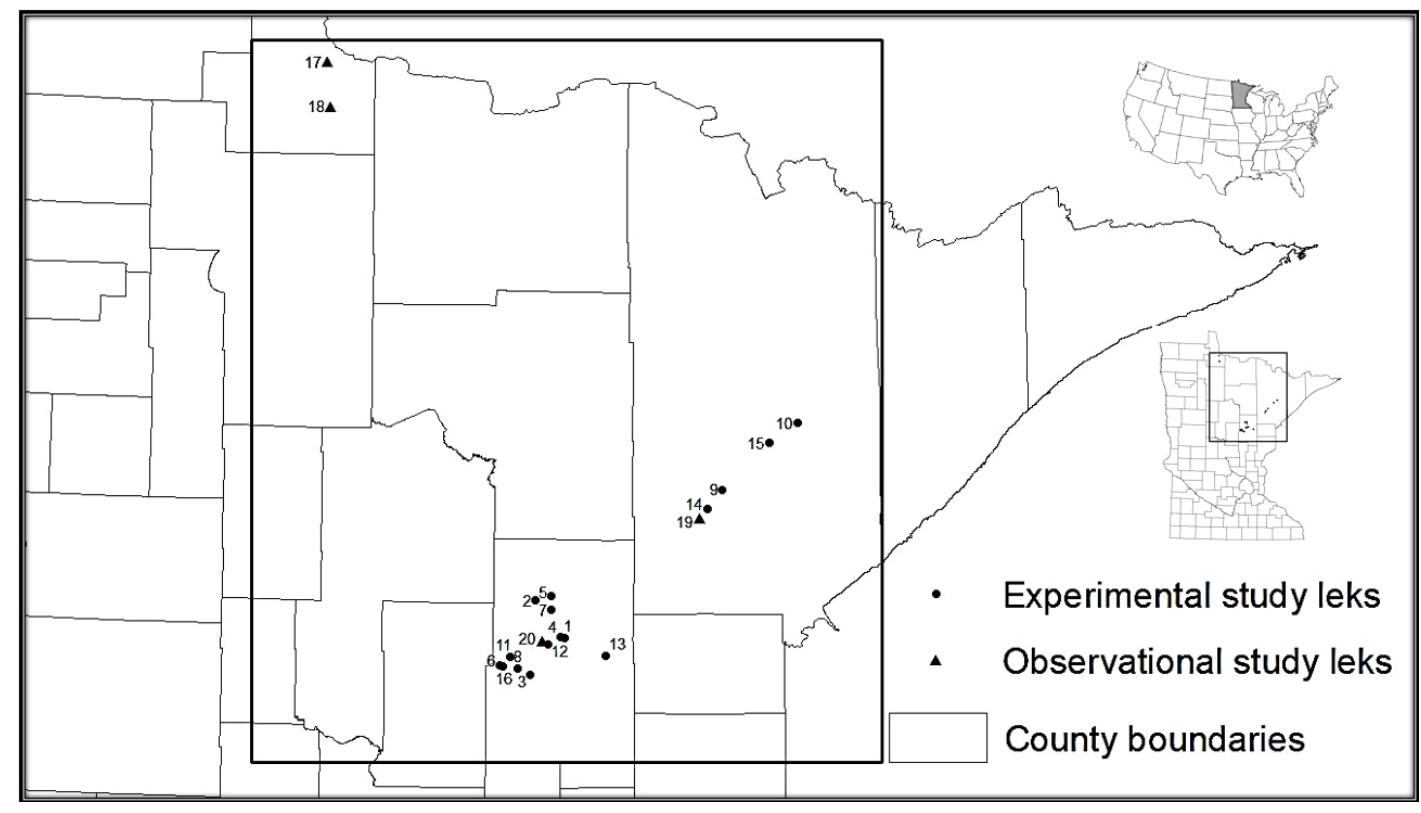

from that distance. Experiments began $\geq 3$ days after blinds were placed to allow birds to acclimate to the blind.

We identified lek pairs consisting of two lekking areas that could be traveled between in $<30 \mathrm{~min}$. Each lek pair was visited once per week to simulate human disturbance during April and May. We defined human disturbance as walking to the blind and getting inside and sitting quietly. We did not deliberately attempt to flush birds off the lek. We simulated human disturbance at lekking areas and documented grouse return times during two periods, "early" disturbance, $15 \mathrm{~min}$ before sunrise (to simulate disturbance analogous to late arrival of observers) and "late" disturbance, $1.5 \mathrm{hr}$ after sunrise (to simulate disturbance analogous to early departure of observers). For early disturbances, we arrived at the parking location with enough time to settle into the blind 15 min before sunrise and then left the blind $45 \mathrm{~min}$ after sunrise, i.e., $1 \mathrm{hr}$ in the blind. We then traveled to the second lek in the lek pair the same day, arriving $1.5 \mathrm{hr}$ after sunrise, and remained until birds left for the morning or 9:00 a.m. (i.e., $\geq$ $1 \mathrm{hr}$ in the blind). Early and late treatments were alternated for each lek pair each week, and for a different lek pair each day, such that a maximum of six lek pairs (12 leks) were visited each week, and a control visit was conducted at one lek on the seventh day. For control visits to leks, we followed the guidelines provided by managers to minimize disturbance; we arrived $45 \mathrm{~min}$ before sunrise (under cover of darkness), settled into the blind $30 \mathrm{~min}$ before sunrise, and stayed until the birds left or 9:00 a.m.

Upon arrival at lekking areas we used a Kestrel ${ }^{\circledR} 2000$ Handheld Anemometer (Boothwyn, Pennsylvania) to measure temperature and wind speed. We also noted wind direction, cloud cover, and any precipitation, i.e., none/light/heavy, or fog. As we approached the blind, we counted the number of birds that flushed as well as any birds that did not flush. We visually estimated the distance (m) at which birds flushed as we approached (hereafter, the flushing distance), as well as the distance that birds flushed (hereafter, the distance to escape cover). We recorded the time (min) until each bird returned in response to disturbances of all types including human disturbance upon arrival, movements within the blind, raptors, and unknown sources. We noted whether birds returned to central or edge positions, or moved between central and edge positions on the lek when returning.

We performed two analyses to test hypotheses with our experimental data, one analysis of lek attendance at the lek level and the other at the bird level for return times after disturbance. At the lek level, our response variable was the time ( $\mathrm{min}$ ) without birds on the lek in the $60 \mathrm{~min}$ after observer arrival. We included instances when birds were not in attendance at leks when we arrived and thus were not disturbed. For this analysis, return of just one bird to the lek meant that birds were no longer absent from the lek. We used a generalized linear mixed model with lek as a random effect and a restricted maximum likelihood method (REML). We evaluated treatment effects (early disturbance, late disturbance, control) and used the control as the reference treatment. We also examined additional explanatory variables based on the literature (Drummer et al. 2011, Cowles and Gibson 2015) after examining variables for correlations $(r>0.7)$. Variables included in the model were standardized Julian date, Julian date squared (for a quadratic effect of date, i.e., a peak in attendance), maximum lek count that day, as well as temperature and average windspeed. For the bird-level analysis, we used a second 
generalized linear mixed model with lek as a random effect and REML to examine return times (min) of individual birds after disturbance as a function of treatment (early disturbance, late disturbance, control), disturbance type (observer arrival, raptor, observer movement), standardized Julian date, standardized Julian date squared (for quadratic effects of date), sex, position on the lek (e.g., center vs. edge), maximum lek count that day, temperature, and average windspeed. Return times for each bird were calculated as the difference between the flush time for the disturbance and the arrival time at the lek after a disturbance. Because birds were unmarked, we assumed that birds arriving at the lek after a disturbance were the same birds returning. Importantly, each unmarked bird arriving at the lek after a disturbance was included in the analysis, but non-returning birds were excluded from the analysis (the return time was undefined). For birds that stayed on the lek when others flushed in response to disturbance we used a return time of $0 \mathrm{~min}$. The references in this analysis were treatment $=$ control, disturbance type $=$ observer arrival, sex $=$ female, and lek position = center. We used package lmerTest (Kuznetsova et al. 2020) in program R (R Core Team 2018) for statistical comparisons. We used "anova" function in lmerTest to provide $\mathrm{p}$-values for each factor and "summary" function to provide $p$-values for each parameter using Satterthwaite's method with REML, which produces good results with consistent Type I error rates, is not anti-conservative, and is not overly sensitive to sample size based on simulations performed by Luke (2017). We calculated parameter estimates, standard errors, and used $\alpha=0.05$.

\section{Descriptive study}

We set out trail cameras (Bushnell ${ }^{\circledR}$ Aggressor Trophy Cam HD; Overland Park, Kansas) at three and four leks with public viewing blinds in 2018 and 2019, respectively. Managers in the east-central region provided written guidelines to observers for blind use, which included directions to arrive $45 \mathrm{~min}$ before sunrise (in the dark), to be quiet and move as little as possible, to try to stay in the blind until the birds left or dancing stopped approximately $2.5 \mathrm{hr}$ after sunrise, and to leave quickly and quietly. Managers in the northwestern region communicated guidelines verbally. We did not provide guidance to managers about how far to place blinds from the lek, which they placed $0 \mathrm{~m}$ from five leks, $6.5 \mathrm{~m}$ from one lek, and $60 \mathrm{~m}$ from the remaining lek. We placed one camera $1-6 \mathrm{~m}$ from the blind to record the blind door opening and closing, and we placed one to three cameras 3-50 $\mathrm{m}$ from the nearest birds to document birds arriving and departing from the lek. We posted a sign to notify people that cameras were present on site, but we did not inform observers of the cameras prior to arrival to prevent bias in arrival times. We programmed the camera aimed at the blind to capture one photo each time it was motion triggered. We programmed cameras viewing the lek to capture two or three photos each min during the morning activity period to capture birds in attendance while preventing memory cards from filling up too quickly; at two sites, we programmed an additional camera to capture a $30 \mathrm{sec}$ or $60 \mathrm{sec}$ video every $5 \mathrm{~min}$ during the same period. We determined when observers arrived and departed from blinds and whether they may have disturbed birds on the lek. When possible, we determined if birds were on the lek when observers arrived and departed and how long it took them to return; however, the time stamps recorded by cameras were not accurate, complicating comparisons between events recorded by the camera directed at the blind and those viewing the lek. Because the time recorded was not reliable, we evaluated observer arrivals relative to ambient light, i.e. dark, semi-light, or light, each day. Return times of birds were estimated from a single camera.

\section{RESULTS}

We placed portable viewing blinds at nine Sharp-tailed Grouse lekking areas between 13 April 2018 and 11 May 2018 and at 12 lekking areas between 6 April 2019 and 10 May 2019 (Table 1). Five leks were included in both years, so 16 of the 30 known leks in the region were studied (Roy 2018, 2019). Lek size (i.e., maximum lek count) was $7.1 \pm 1.3$ (range: $2-13$ ) in 2018 and 7.8 \pm 1.7 (range: $3-25$ ) in 2019 .

We conducted experiments to simulate early morning disturbances on 35 occasions, to simulate late disturbances on 36 occasions, and visited leks for control observations on 13 occasions. We visited blinds at each lek 2-6 times, with more visits to leks for which Sharp-tailed Grouse were not in attendance on more than one morning (Table 1). One lek was only visited once for a control observation because bird attendance was inconsistent. Observers spent $60 \pm 1 \mathrm{~min}$ in the blind for early disturbances, $76 \pm 2 \mathrm{~min}$ for late disturbances, and $218 \pm 6 \mathrm{~min}$ for controls.

\section{Lek attendance at experimental blinds}

Sharp-tailed Grouse were not at leks when we arrived on 32 occasions, 12 early (34\%), 16 late (44\%), and at four control observations (31\%), and thus we did not disturb them when we arrived. On 13 of 32 occasions, birds did eventually come an average of $34 \pm 10 \mathrm{~min}$ later (1-130 $\mathrm{min})$. On 19 of the 32 occasions, however, Sharp-tailed Grouse did not arrive at all while we were in blinds, of which 16 involved five leks where lek attendance was erratic. Two of these occasions with no birds in attendance occurred before 8 April and eight occasions occurred after 1 May. Precipitation conditions were generally favorable for observations (Drummer et al. 2011, Hanson 2021), but on two mornings it rained heavily and birds did not come to the lek while we were there (Table 1). Average wind exceeded $16 \mathrm{kmh}^{-1}$ on three additional mornings $\left(17,22\right.$, and $\left.23 \mathrm{kmh}^{-1}\right)$, but birds were on the lek all three mornings.

We noted female attendance at leks on 13 occasions during the two-year study period between 13 April and 4 May with the average Julian date of attendance being 28 April for both years combined. The time of female arrival at leks was usually very early but on four occasions females arrived at 7:45 AM or later. We observed mating on control leks twice and observed malefemale "pairs" of birds leaving leks during control observations six times, but we never observed similar behavior during observations at disturbance treatments.

Sharp-tailed Grouse moved their focal activity area from the originally identified area, based on fecal pellets and observations, an average of $35 \pm 7 \mathrm{~m}$ (range: $0-200 \mathrm{~m}, n=36$ ) from blinds. However, on $\geq 17$ occasions birds changed their focal activity area $\geq 15 \mathrm{~m}$ between visits each week. In $8 \%$ of visits they moved closer to the blind than in a previous visit, $42 \%$ of visits they moved 
Table 1. Sharp-tailed Grouse (Tympanuchus phasianellus) leks used in the experimental study at viewing blinds in Minnesota, USA during 2018-2019. Maximum lek counts were taken each day birds were in attendance. The number of days that no birds were in attendance on arrival is noted, as well as the maximum number of birds not returning after any type of disturbance, the mean return time of birds after human disturbance (for those that returned), and the average number of min in the first hr after early and late observations when no birds were in attendance at leks (for any reason, including human disturbances, raptors, arriving after we arrived, not arriving at all). Lek 12 was not included in the experimental treatments because birds were never consistently in the same location but it is reported here to document inconsistencies in lek attendance. Leks are listed in order of declining lek counts, except when a lek was observed in both years of the study $(n=5)$.

\begin{tabular}{|c|c|c|c|c|c|c|c|c|}
\hline Lek & Year & Visits & $\begin{array}{l}\text { Max lek counts } \\
\text { (birds) }\end{array}$ & $\begin{array}{l}\text { No birds on } \\
\text { arrival } \\
\text { (days) }\end{array}$ & $\begin{array}{l}\text { Max birds not returning } \\
\text { after disturbance } \\
\text { (birds) }\end{array}$ & $\begin{array}{l}\text { Mean return after } \\
\text { human } \\
\text { disturbance (min) }\end{array}$ & $\begin{array}{l}\text { Mean time off } \\
\text { lek early (min) }\end{array}$ & $\begin{array}{c}\text { Mean time off lek } \\
\text { late (min) }\end{array}$ \\
\hline 1 & 2019 & 5 & $13-25$ & 1 & 0 & 21 & 0 & 40.5 \\
\hline 2 & 2018 & 2 & $12-13$ & - & 0 & 24 & 32 & 13 \\
\hline 3 & 2018 & 4 & $8-13$ & - & 0 & 16 & 23 & 12.5 \\
\hline 3 & 2019 & 6 & $2-5$ & 6 & 1 & - & 47 & 30.5 \\
\hline 4 & 2019 & 5 & $4-12$ & - & 7 & 9 & 0 & 35 \\
\hline 5 & 2018 & 3 & $5-7$ & - & 7 & 14 & 34 & 60 \\
\hline 5 & 2019 & 4 & $6-9$ & - & 7 & 30 & 11.5 & 38.5 \\
\hline 6 & 2018 & 2 & $7-8$ & - & 2 & 24 & 23 & 13 \\
\hline 6 & 2019 & 6 & $1-8$ & 4 & 6 & 29 & 44.5 & 38 \\
\hline 7 & 2018 & 3 & $4-8$ & - & 1 & 15 & 1 & 21 \\
\hline 7 & 2019 & 3 & $2-7$ & $2^{\dagger, \hbar}$ & 3 & 29 & 28 & 34.5 \\
\hline 8 & 2018 & 2 & $3-6$ & - & 0 & 19 & 5 & 47 \\
\hline 8 & 2019 & 6 & $1-7$ & 3 & 7 & - & - & 60 \\
\hline 9 & 2019 & 6 & $1-6$ & $4^{\dagger}$ & 3 & - & 60 & 59 \\
\hline 10 & 2019 & 5 & 5 & - & 5 & 47 & 43 & 60 \\
\hline 11 & 2019 & 5 & $1-5$ & $2^{*}$ & 2 & 7 & 0 & 25.5 \\
\hline 12 & 2018 & 1 & 4 & $1^{*}$ & 0 & - & - & - \\
\hline 13 & 2018 & 2 & $2-3$ & - & 2 & 33 & 60 & 33 \\
\hline 14 & 2019 & 6 & 3 & 5 & 0 & - & 43.5 & 42 \\
\hline 15 & 2019 & 5 & 3 & 5 & 0 & - & 33.5 & 60 \\
\hline 16 & 2018 & 2 & 2 & - & 1 & 11 & 12 & 42 \\
\hline
\end{tabular}

farther from the blind than a previous visit, and $50 \%$ of visits they were the same distance from the blind $(<15 \mathrm{~m})$ as the last visit. The distance between activity areas, relative to the blind, ranged from $0-140 \mathrm{~m}$.

\section{Responses to disturbance at experimental blinds}

We visually estimated average flushing distance to be $53 \pm 4 \mathrm{~m}$ (range: $15-100, n=44$ ), with Sharp-tailed Grouse flushing to escape cover an average of $101 \pm 12 \mathrm{~m}$ from blinds (range: 25 $300, n=30$, sometimes it was too dark or foggy to see). A subset of birds ( $2.1 \pm 0.4$ birds, range: $1-5)$ did not flush when we arrived on 17 occasions, eight early, five late, and four control. Leks where birds stayed when we arrived ranged in size from 4-25 birds and birds were $21 \pm 7$ m away from blinds on these mornings (20 April5 May 2018 and 10-28 April 2019).

On 13 occasions, at seven early- and six late-disturbed leks, some birds did not return after observers flushed them (average 3.0 \pm 0.8 birds and $4.5 \pm 1.0$ birds, respectively), and these leks had a maximum count that day that ranged $2-8$ birds. On six of these 13 occasions $(46 \%)$, three early and three late, no birds returned while we were in blinds ( $\geq 1 \mathrm{hr})$.

Generalized linear mixed models of the time during which no birds were present on leks after observer arrival included significant effects of treatment (early disturbance, late disturbance, control), temperature, and maximum lek count that day (Table 2A, B). Birds were absent from leks longer when maximum counts were lower that day, i.e., fewer birds were in attendance that day, and during colder temperatures. Birds were absent from leks longer during late morning observation periods

Sharp-tailed Grouse were flushed off leks for reasons other than human arrivals including raptors, American Crows (Corvus brachyrhynchos), Common Ravens (Corvus corax), observer movements within the blind, and unknown reasons. Raptors, including Northern Harriers (Circus hudsonius) and Roughlegged Hawks (Buteo lagopus), disturbed birds off leks on 10 of 17 occasions, four flushes occurred during six early raptor visits, six flushes occurred during 11 late raptor visits. The first Sharptailed Grouse returned $10 \pm 6$ min after being flushed by raptors, but on three occasions, birds did not return. The proportion of birds not returning, when some but not all birds did not return, was $67 \%$ for human disturbances (range: $12.5-100 \%, n=13$ ) and $55 \%$ for raptors (range: $14-100 \%, n=3$ ). Sharp-tailed Grouse also flushed off leks after observers moved in the blind (return time $12 \pm 3$ min, $n=5$ ). American Crows and Common Ravens flushed Sharp-tailed Grouse on three occasions with an average return time of the first bird of $17 \pm 7 \mathrm{~min}$; in one case the crow was chasing a male grouse and coming within $\sim 0.3 \mathrm{~m}$ of the bird 
Table 2. Estimated regression parameters and statistics from a generalized linear mixed effect model of lek attendance with lek as a random effect using Satterthwaite's method with REML and the "summary" and "anova" functions in R lmerTest (Luke 2017). Significant variables are indicated with an asterisk.

\begin{tabular}{|c|c|c|c|c|c|c|}
\hline A) Satterthwaite's method with REML in "summary" function & & Estimate & $\begin{array}{c}\text { Standard } \\
\text { Error }\end{array}$ & df & $\mathrm{T}$ value & $\operatorname{Pr}(>|t|)$ \\
\hline Intercept & & 35.57 & 7.53 & 55.2 & 4.72 & $1.64 \mathrm{e}-05^{*}$ \\
\hline Treatment $=$ Early; reference $=$ Control & & 7.63 & 6.68 & 64.34 & 1.14 & 0.26 \\
\hline Treatment $=$ Late; reference $=$ Control & & 17.13 & 6.92 & 65.61 & 2.48 & $0.016^{*}$ \\
\hline Julian Date & & 4.71 & 2.47 & 73.52 & 1.91 & 0.06 \\
\hline$(\text { Julian Date })^{2}$ & & 1.27 & 2.19 & 62.97 & 0.58 & 0.56 \\
\hline Arrival temperature & & -1.17 & 0.49 & 72.96 & -2.36 & $0.021 *$ \\
\hline Average windspeed & & -0.54 & 0.75 & 69.54 & -0.71 & 0.48 \\
\hline Maximum count at lek on day & & -2.16 & 0.58 & 31.82 & -3.76 & $0.0007^{*}$ \\
\hline B) Satterthwaite's method with REML in "anova" function & Sum Squares & $\begin{array}{c}\text { Mean } \\
\text { Square }\end{array}$ & Num df & Denom df & $\mathrm{F}$ value & $\operatorname{Pr}(>\mathrm{F})$ \\
\hline Treatment & 2745.1 & 1372.5 & 2 & 62.9 & 3.70 & $0.030 *$ \\
\hline Julian Date & 1347.6 & 1347.6 & 1 & 73.52 & 3.63 & 0.061 \\
\hline$(\text { Julian Date })^{2}$ & 124.6 & 124.6 & 1 & 62.97 & 0.34 & 0.56 \\
\hline Arrival temperature & 2068.5 & 2068.5 & 1 & 72.96 & 5.58 & $0.021 *$ \\
\hline Average windspeed & 186.3 & 186.3 & 1 & 69.54 & 0.50 & 0.48 \\
\hline Maximum count at lek on day & 5238.6 & 5238.6 & 1 & 31.82 & 14.12 & $0.0007^{*}$ \\
\hline
\end{tabular}

on the ground, but birds did not flush two other times when crows flew over the lek. On 40 occasions, more than one male Sharptailed Grouse flushed or departed for an unknown reason.

Generalized linear mixed models of return times for individual birds after disturbances indicated that birds took longer to return when disturbed by human observers arriving than after observer movements within the blind or disturbances by raptors (Table $3 \mathrm{~A}$, B). However, birds took similar lengths of time to return to leks after late-disturbance treatments as early-disturbance treatments and controls. Smaller lek size, edge positions on the lek, and windy conditions also were related to longer return times in bird-level analyses. We did not detect significant fixed effects of sex. However, we had a small number of observations of females returning to leks compared to those for males. Return times did show a quadratic relationship with date, indicating shorter return times during the middle of the season, which coincided with higher female attendance at leks (Fig. 2).

\section{Descriptive study}

In the east-central Sharp-tailed Grouse region, wildlife managers placed cameras at a viewing blind on public land with a lek of 27 birds in 2018 and 12 birds in 2019 (Table 4). For the 16 visits that we captured on camera, $68 \%$ of visits lasted $<2 \mathrm{hr}$ and $13 \%$ lasted $<1 \mathrm{hr}$. Five parties arrived under cover of darkness, 10 arrived when semi-light, and one when it was fully light. Birds moved away from the blind after 20 April 2018. On four occasions, at least one observer came out of the blind during the visit. Birds flushed off the lek at least three times when observers departed. Thick vegetation made determination of return times almost impossible; we could only determine two return times of $18 \mathrm{~min}$ after an observer arrival and $32 \mathrm{~min}$ after a departure. At a second lek in the east-central region on private land with six males in both 2018 and 2019, cameras captured 14 visits (Table 4): two visits by a lone photographer and five other parties arrived while dark, five parties arrived while it was semi-light, and two arrived when it was fully light. Sixty percent of visits lasted $>2 \mathrm{hr}$ and none lasted $<1 \mathrm{hr}$. The birds seemed tolerant of people, with one bird staying on the lek while a person approached. On another occasion, the birds were dancing as people entered the blind, and a grouse sat on top of the blind while observers were inside in both years. Birds were on the lek when visitors departed on at least seven occasions; however, return times could not be determined because of camera positioning and time stamp issues.

Fig. 2. Male attendance (number of birds) and average return times ( $\mathrm{min}$ ) after all types of disturbance at Sharp-tailed Grouse (Tympanuchus phasianellus) leks in Minnesota, USA as a function of Julian date and with reference to dates of female attendance during 2018-2019. The black dotted line is a quadratic relationship between lek count and date; the gray dotted line is a quadratic relationship between average return time and date.

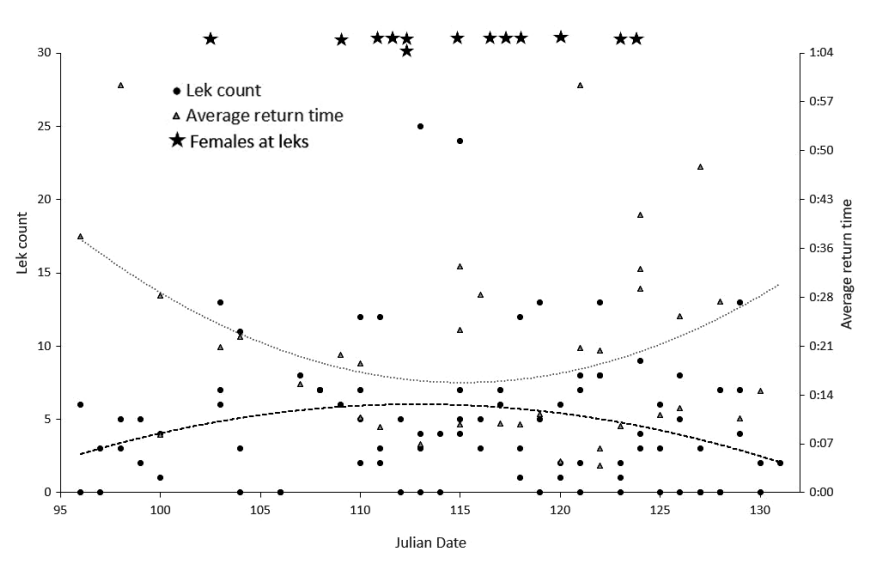

In the northwestern Sharp-tailed Grouse region, we monitored a viewing blind at a lek on private land with 15 and 16 birds in 2018 and 2019, respectively (Table 4). The camera captured 17 visits, 
Table 3. Estimated regression parameters and statistics from a generalized linear mixed effect model of return times after disturbance with lek as a random effect using Satterthwaite's method with REML and the 'summary' and 'anova' functions in R lmerTest (Luke 2017). Significant variables are indicated with an asterisk.

\begin{tabular}{|c|c|c|c|c|c|c|}
\hline \multicolumn{2}{|c|}{$\begin{array}{l}\text { A) Fixed effect in lmerTest with } \\
\text { Satterthwaite's method with REML in } \\
\text { 'summary' function }\end{array}$} & Estimate & Standard error & df & $\mathrm{t}$ value & $\begin{array}{l}\operatorname{Pr}(>|t|) \text { value for } \\
\text { factor }\end{array}$ \\
\hline \multicolumn{2}{|c|}{ Intercept } & 44.61 & 10.24 & 49.7 & 4.36 & $6.63 \mathrm{e}-05^{*}$ \\
\hline \multicolumn{2}{|c|}{ Treatment $=$ Early; reference $=$ Control } & -3.09 & 2.98 & 162.3 & -1.04 & 0.30 \\
\hline \multicolumn{2}{|c|}{ Treatment $=$ Late; reference $=$ Control } & -3.44 & 3.98 & 161.5 & -0.87 & 0.39 \\
\hline \multicolumn{2}{|c|}{ Julian Date } & -0.29 & 0.25 & 162.4 & -1.18 & 0.24 \\
\hline \multicolumn{2}{|c|}{$(\text { Julian Date })^{2}$} & 0.06 & 0.02 & 163.0 & 3.76 & $0.0002 *$ \\
\hline \multicolumn{2}{|c|}{$\begin{array}{l}\text { Disturbance }=\text { Observer Move } \text {, reference }= \\
\text { Observer Arrival }\end{array}$} & -10.12 & 4.58 & 154.5 & -2.21 & $0.03 *$ \\
\hline \multicolumn{2}{|c|}{$\begin{array}{l}\text { Disturbance }=\text { Raptor; reference }=\text { Observer } \\
\text { Arrival }\end{array}$} & -5.24 & 1.32 & 146.38 & -3.98 & $0.0001^{*}$ \\
\hline \multicolumn{2}{|c|}{ Sex $=$ Male $;$ reference $=$ Female } & -4.01 & 4.37 & 143.98 & -0.92 & 0.36 \\
\hline \multicolumn{2}{|c|}{ Maximum lek count on day of disturbance } & -2.21 & 0.54 & 56.42 & -4.10 & $0.0001 *$ \\
\hline \multicolumn{2}{|c|}{$\begin{array}{l}\text { Lek position }=\text { both center and edge; } \\
\text { reference }=\text { Center }\end{array}$} & 9.11 & 1.91 & 162.89 & 4.76 & $4.28 \mathrm{e}-06^{*}$ \\
\hline \multicolumn{2}{|c|}{ Lek position $=$ edge reference $=$ Center } & 4.96 & 1.33 & 152.2 & 3.73 & $0.0003^{*}$ \\
\hline \multicolumn{2}{|c|}{ Arrival temperature } & -0.78 & 0.45 & 131.9 & -1.74 & 0.08 \\
\hline \multicolumn{2}{|l|}{ Average windspeed } & -1.02 & 0.31 & 160.9 & -3.24 & $0.001 *$ \\
\hline \multicolumn{2}{|l|}{$\begin{array}{l}\text { B) Satterthwaite's } \\
\text { method with REML } \\
\text { in "anova" function }\end{array}$} & Mean Square & Num DF & Denom DF & F value & $\operatorname{Pr}(>F)$ for parameter \\
\hline Treatment & 39.40 & 19.70 & 2 & 160.52 & 0.54 & 0.58 \\
\hline Julian Date & 50.91 & 50.91 & 1 & 162.41 & 1.39 & 0.24 \\
\hline$(\text { Julian Date })^{2}$ & 516.72 & 516.72 & 1 & 162.99 & 14.12 & $0.0002 *$ \\
\hline Disturbance type & 846.74 & 423.37 & 2 & 149.01 & 11.57 & $2.14 \mathrm{e}-05^{*}$ \\
\hline Sex & 30.79 & 30.79 & 1 & 143.98 & 0.84 & 0.36 \\
\hline $\begin{array}{l}\text { Maximum lek count } \\
\text { on day of disturbance }\end{array}$ & 613.78 & 613.78 & 1 & 56.42 & 16.77 & $0.0001^{*}$ \\
\hline Lek position & 910.04 & 455.02 & 2 & 156.08 & 12.43 & $9.76 \mathrm{e}-06^{*}$ \\
\hline Arrival temperature & 110.43 & 110.43 & 1 & 131.91 & 3.02 & 0.08 \\
\hline Average windspeed & 382.91 & 382.91 & 1 & 160.89 & 10.46 & $0.0015^{*}$ \\
\hline
\end{tabular}

including one visit with a woman and her dog (Fig. 3), with $25 \%$ of visits lasting $>2 \mathrm{hr}$ and $50 \%$ lasting $<1 \mathrm{hr}$. Three parties arrived while it was dark, seven when it was semi-light, and six when it was light. One individual arrived when it was semi-light and birds were already on the lek and wandered around the lek for $36 \mathrm{~min}$ instead of entering the blind. This disrupted activity on the lek for $\geq 56 \mathrm{~min}$, although birds did return to the lek for $9 \mathrm{~min}$ before leaving again. When one party arrived, no birds were on the lek. On another occasion, a group of five put up a portable blind next to the public blind the afternoon prior to their morning visit, observed the lek again prior to sunset that evening, then removed the portable blind afterward. We could not always determine return times for birds after flushing, but, when we could, birds flushed by arriving observers returned after $4.5 \pm 1.5 \mathrm{~min} \mathrm{(2-12}$ $\min , n=6$ ) and when observers departed, birds returned after 6 $\pm 2 \min (1-14 \mathrm{~min}, n=8)$, with birds returning more rapidly when observers left quickly. However, one party did not leave the area for $15 \mathrm{~min}$ and birds returned to the lek after $27 \mathrm{~min}$. We could not determine return times for two other parties: one that wandered around the lek for $21 \mathrm{~min}$ before leaving and another that spent 27 min taking down a portable blind. At a second public viewing blind on private land in the northwestern region with 16 birds in 2019 (Table 4), we documented 11 visits on nine days including two evening visits. One group put up a portable blind next to the public blind during the afternoon and used it that
Fig. 3. A person arriving at a Sharp-tailed Grouse (Tympanuchus phasianellus) viewing blind almost 20 minutes after sunrise (late) with a dog. Sharp-tailed Grouse were on the lek before their late arrival, but flushed as they approached the lek.

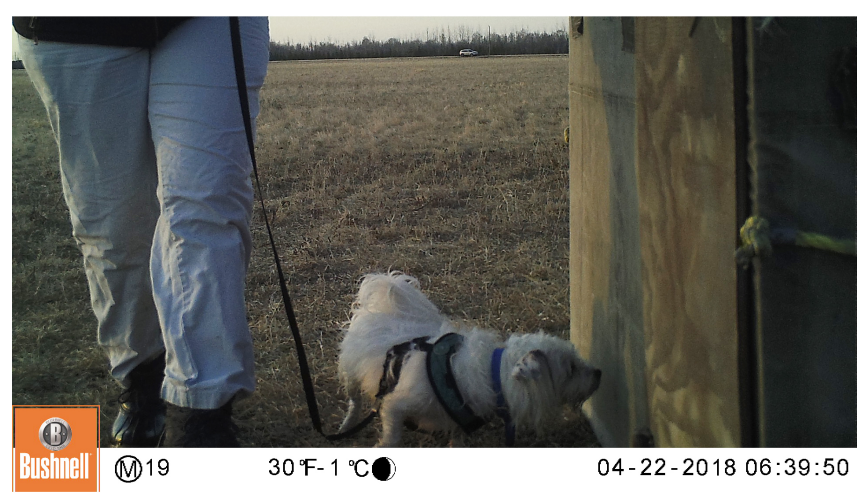

evening. Forty-five percent of visits lasted $>2 \mathrm{hr}$ and $27 \% \leq 1 \mathrm{hr}$. During morning visits, four parties arrived in the dark, three when it was semi-light, and two when it was light. Birds were not on the 
Table 4. Sharp-tailed Grouse (Tympanuchus phasianellus) leks used in the descriptive study of public viewing blinds in Minnesota, USA during 2018-2019, including the region (east-central [EC], northwest [NW]), land ownership (public [Pub] or private [Pvt]), lek count, camera set dates, blind reservation dates, number of days reserved, number of people reserving the blind, dates and visits in photos or videos recorded by the camera, the number of people in each group (grp), and durations of time people stayed in viewing blinds each visit.

\begin{tabular}{lcccccccccccc}
\hline \hline Lek & Year & Region & Own & $\begin{array}{c}\text { No. } \\
\text { birds }\end{array}$ & $\begin{array}{c}\text { Camera set } \\
\text { month/day }\end{array}$ & $\begin{array}{c}\text { Reserve } \\
\text { month/day }\end{array}$ & $\begin{array}{c}\text { People } \\
\text { reserve }\end{array}$ & $\begin{array}{c}\text { Reserve } \\
\text { days }\end{array}$ & $\begin{array}{c}\text { Cam record dates } \\
\text { month/day }\end{array}$ & $\begin{array}{c}\text { Cam } \\
\text { visits } \\
\text { (days) }\end{array}$ & $\begin{array}{c}\text { Grp } \\
\text { size }\end{array}$ & $\begin{array}{c}\text { Stay length in min } \\
\text { mean } \pm \text { SE (range) }\end{array}$ \\
\hline 20 & 2018 & EC & Pub & 27 & $4 / 9-5 / 10$ & $4 / 9-4 / 30$ & 9 & 12 & $4 / 12-4 / 30^{\dagger}$ & 7 & $1-4$ & $119 \pm 23(26-214)$ \\
20 & 2019 & EC & Pub & 12 & $4 / 3-5 / 9$ & $4 / 4-4 / 30$ & 9 & 12 & $4 / 4-4 / 30$ & 9 & $1-3$ & $91 \pm 13(35-158)$ \\
19 & 2018 & EC & Pvt & 6 & $4 / 10-5 / 15^{\ddagger}$ & NA & NA & NA & $5 / 4-5 / 12$ & 4 & $1-3$ & $201 \pm 11(181-221)$ \\
19 & 2019 & EC & Pvt & 6 & $3 / 27-5 / 20$ & NA & NA & NA & $3 / 29-5 / 8$ & 10 & $1-3$ & $151 \pm 19(93-272)$ \\
17 & 2018 & NW & Pvt & 15 & $4 / 9-5 / 21$ & $3 / 21-5 / 6$ & 10 & 13 & $4 / 11-5 / 5$ & 8 & $1-3$ & $61 \pm 11(28-126)$ \\
17 & 2019 & NW & Pvt & 16 & $4 / 9-5 / 14$ & $4 / 16-5 / 3$ & 8 & 9 & $4 / 16-5 / 3$ & $9(8)$ & $1-5$ & $111 \pm 22(42-228)$ \\
18 & 2019 & NW & Pvt & 16 & $4 / 10-5 / 14$ & $4 / 16-5 / 10$ & 10 & 11 & $4 / 18-5 / 10$ & $11(9)$ & $1-3$ & $134 \pm 26(51-336)$ \\
\hline
\end{tabular}

Camera not operational 25-29 April 2018 because post shifted as ground thawed;

${ }^{*}$ Camera not operational until 30 Apr 2018 because post shifted as ground thawed;

${ }^{\S}$ Reservations not retained at this blind in either year.

lek when one party arrived but were on the lek when two parties arrived in the dark. Average return times were $4 \pm 1 \min (2-9 \mathrm{~min}$, $n=5)$ after observer arrivals and $9 \pm 2 \min (4-14 \min , n=5)$ after observer departures. A return time could not be determined for a party that left while birds were on the lek and spent $41 \mathrm{~min}$ outside the blind before leaving. Birds had not returned after 51 min when the camera stopped prematurely. Birds were on the lek in at least seven instances when observers departed, including two when birds were actively displaying.

\section{DISCUSSION}

\section{Inconsistencies in lek attendance}

We studied a small and declining Sharp-tailed Grouse population with viewing blinds and documented inconsistencies in lek attendance, with long periods of the morning when no birds were present at leks, both in response to and in the absence of disturbance. Sharp-tailed Grouse were not in attendance at leks when we arrived on more than a third of lek visits and spent considerable periods off leks in the morning. Sometimes birds arrived later the same morning, and it is possible that some of these absences might be explained by disturbance by a predator or other source prior to our arrival. However, Johnsgard (2002:23), with reference to a study by Lehmann 1941 of Attwater's Prairie Chicken Tympanuchus cupido attwateri), suggested inconsistent lek attendance might be "the mark of a dispersed and possibly declining population," which is consistent with survey data for this population (Roy 2019). In our experimental study, return times to leks were longer after human disturbance than after disturbance by raptors. After disturbance at leks, birds sometimes did not return at all or only a portion of birds returned, further reducing attendance at the lek. The time that birds spent off the lek was greater when disturbances occurred later in the morning compared to controls. Our descriptive study of public blinds documented observers arriving late, leaving early, and staying for various lengths of time inconsistent with the manager-recommended guidelines. Our data on human behaviors at public viewing blinds indicate that blinds create an additional source of disturbance at leks. In sum, disturbance at viewing blinds in this declining population may further exacerbate inconsistencies in lek attendance, with longer return times in response to arrival of human observers than other disturbances.

Lek attendance of Sharp-tailed Grouse is usually highest within three hours of sunrise (Kermott 1982, Drummer et al. 2011, Cowles and Gibson 2015); therefore, long absences or multiple absences after repeated disturbances could comprise a substantial portion of the morning when males are typically in attendance at leks. If disturbed twice by humans arriving and departing viewing blinds, and also being disturbed by raptors the same morning, lek attendance may be reduced by $25-30 \%$ in a given morning. Some absences might be explained by lower attendance later in the morning; Drummer et al. (2011) found lek counts were highest around sunrise and declined later in the morning early in the season, but birds were more consistently at leks later in the morning, i.e., $3 \mathrm{hr}$ after sunrise, during the peak of the lekking season. Cowles and Gibson (2015) found female attendance was highest around sunrise. Thus, our observations of lower attendance later in the morning can be at least partially explained by patterns of lek attendance outside the peak of lekking season, although date was not important in our analysis. Moreover, absences after late disturbances were longer than during control observations for the same periods, indicating that disturbances later in the morning, when females are less likely to be in attendance, may impact male lek attendance more.

We also noted inconsistencies in lek locations where territories were not fixed throughout the season. We considered the possibility that the birds were moving in response to the viewing blinds. Other studies have placed viewing blinds farther from leks (50 $\mathrm{m}$ from center in Flock et al. 2002, $45 \mathrm{~m}$ from lek in Corace et al. 2018). However, birds would sometimes move farther from the blind, sometimes closer and even landing on the blind on a few occasions, and sometimes they would not move at all. Therefore, it was not clear that the birds were responding to the blind. Lek movements $(30.5 \mathrm{~m})$ have been noted in other studies 
of Sharp-tailed Grouse in response to snowfall and flooding, but males maintained their relative positions to each other (Tsuji 1992). In our study, snow depth was $>7.5 \mathrm{~cm}$ on only three mornings; therefore, snow cover is unlikely to explain the lek movements. We are not sure why leks moved short distances among visits, but given the other inconsistencies in lek attendance, inconsistency seems to be pervasive in this small, declining population.

\section{Responses to disturbance at leks}

When birds did return to leks, fewer birds returned after disturbances that occurred later in the morning than after early disturbances. Fewer males might have returned to leks after late disturbances because they were less likely to encounter and mate with females successfully later in the morning; female visits to leks were usually closer to sunrise (Drummer et al. 2011, Cowles and Gibson 2015). Males also returned to disturbed leks fastest during the seasonal peak in lek attendance, when female attendance was higher. Males arriving or returning to leks first also occupied more central positions on the lek, so were likely older males (Wiley 1974, Gratson et al. 1991, Tsuji et al. 1994), and females select males in more central positions (Hjorth 1970, Wiley 1974, Tsuji et al. 1994). Thus, males that returned were probably those that were more likely to mate successfully if females arrived. However, Cowles and Gibson (2015) did not find that the total time male Sharp-tailed Grouse spent on leks increased with female numbers, although male behaviors on the lek varied with female attendance.

Even though absences from leks were longer after late human disturbances than controls, we suggest that early disturbances are more likely to have an effect on reproductive success because of higher female attendance early in the morning (Drummer et al. 2011, Cowles and Gibson 2015). Disturbances that occur while females are in attendance at leks may interfere with or delay mating on the lek (Baydack and Hein 1987). We did not observe mating or pair departures in over 80 hours of observations following human disturbance treatments, but we did observe these behaviors at control leks, despite having nearly half as many hours in control observations $(47 \mathrm{hr})$. These departing pairs of birds may have mated off the lek (Lehmann 1941, Sexton 1979). We did have several instances where females were known to be flushed off the lek during our visits, but, because females were not marked, we cannot know if these particular females later returned. The following cases involved females flushing off leks: three flushed in response to an American Crow and one arrived 24 min later, one flushed for an unknown reason with one arriving 14 min later, two flushed in response to a Rough-legged Hawk and one arrived $23 \mathrm{~min}$ later, and two flushed in response to humans and one arrived $51 \mathrm{~min}$ later. Importantly, females never returned to leks before males did. In most of our disturbance treatments, we did not know the sex of the birds that flushed when we arrived, so we could not examine female responses to human disturbance more explicitly in our study. However, in a telemetry study conducted during 2013-2015 in this population, marked females sometimes did return to the same lek where they were captured, but not consistently (L. Shartell, Minnesota Department of Natural Resources, unpublished data). Females may visit leks multiple times a season and have been observed visiting more than one lek (Landel 1989).
Some types of disturbances were more disruptive than others; birds took longer to return to leks after disturbance by humans than after flushing in response to raptors or observer movements in the blind. Responses to predators often vary with the species, with stronger reactions to Northern Goshawks (Accipter gentilis) and Peregrine Falcons (Falco peregrinus) than Northern Harriers (Sparling and Svedarsky 1978, Connelly et al. 2020). In a Manitoba, Canada study of disturbance at Sharp-tailed Grouse leks, human presence at the center of leks displaced birds, but snow fencing through the lek, parked vehicles (running and not running), propane exploders, scarecrows, scarecrows with taperecorded voices, radio sounds, and a dog on a leash were not disruptive to males (Baydack 1986, Baydack and Hein 1987). In that study, male Sharp-tailed Grouse returned to leks $\leq 15 \mathrm{~min}$ after humans departed the lek, 5-10 min sooner than in our study, although, in our study, humans entered the blind rather than departing. Females were intolerant of disturbance and were not observed at any disturbed lek regardless of the disturbance type, despite female attendance at undisturbed controls and at leks after disturbances were removed (Baydack 1986, Baydack and Hein 1987).

One limitation of our study was that we simulated disturbance of observers departing blinds before birds left for the morning by having observers arrive at blinds 90 min after sunrise, rather than actually departing blinds early. Our protocol made the disturbance treatments more similar, although perhaps compromising exact replication of observers leaving blinds early. We made the decision to increase sample sizes in each treatment in order to minimize unexplained variation among early and late treatments because of day and progression of the season, and to be able to observe returning birds more accurately from within blinds in both treatments. If the birds respond differently to people moving toward the lek than they do to people moving away from the lek, then our methods may not have adequately simulated observers leaving blinds before birds left for the morning. However, we suspect that the birds are responding to human presence or approach, and that, while flushing, they are focused on escape cover not the lek and thus react similarly to human presence whether people emerge from the blind or approach the lek. Similar return times after both treatments is supportive of this interpretation. However, if birds might have returned faster in response to departure of humans from the blind and walking away than they did from human approach, then we would not have captured this in our data. Nevertheless, our conclusions about human disturbance are robust to this possibility.

\section{Implications for conservation}

Our findings have implications for spring monitoring of leks in small, declining populations. Attendance at small leks is usually more consistent around sunrise (Kermott 1982, Drummer et al. 2011), so visiting small leks before large leks, which have higher attendance, may improve detection of small leks in surveys (Sadoti et al. 2016). However, we found inconsistencies in lek attendance around sunrise as well. Leks in small and declining populations may require more numerous short visits, or a longer visit from a safe distance, to improve detection of birds when lek attendance is inconsistent (Sadoti et al. 2016). Flush counts are also used to count leks, but multiple flush counts could exacerbate displacement of birds from leks that already have inconsistent 
attendance and few mating opportunities. The infrequency with which we observed females visiting leks in this study indicates that mating opportunities may be infrequent at small leks in declining populations.

Our findings can inform decisions about providing blinds for public use in small populations that are vulnerable to local extinction. Conservation managers are unlikely to place blinds at leks that have inconsistent lek attendance or few birds, instead opting for larger, more stable leks ( $\geq$ nine birds) to provide reasonably reliable viewing experiences to the public (Oberbillig 2011). Yet, in our study, a public viewing blind was placed at a lek with six males that reliably attended the lek, illustrating that consistent attendance is not necessarily associated with lek size. Managers should provide information to observers during the blind reservation process and stress the importance of compliance to help curb behaviors likely to have negative impacts on the birds (e.g., arriving late, leaving early, not departing the lek area quickly) to minimize disturbance by observers and effects on lek attendance. We found that observers receiving written instructions (east-central region) were more compliant than those receiving verbal instruction only (northwestern region). Monitoring compliance with recommended guidelines may be necessary to ensure that leks in vulnerable populations are not unduly disturbed. Importantly, several of the leks with viewing blinds in the east-central region had fewer birds in later years (Fig. 1 , leks $3,7,19,20)$, although this was not consistent and may have been unrelated to the viewing blinds.

Viewing blinds have been used in stable populations of prairie grouse with no reported adverse effects (Oberbillig 2011), so our findings are likely specific to small, declining populations, and possibly limited to populations in advanced stages of decline. Importantly, return times after human disturbance at public blinds in the more stable northwestern population were notably shorter, averaging 5 or $6 \mathrm{~min}$, than in the smaller east-central population. Responses to disturbance might vary among populations for a variety of reasons such as disturbance frequency, intensity, availability of nearby escape cover, lek size, habitat quality, and consistency in lek attendance, among other reasons (Ydenberg and Dill 1986, Smit and Visser 1993, Laursen et al. 2005, Stankowich and Blumstein 2005, Baines and Richardson 2007, Thiel et al. 2007). We did not quantify reproductive success or survival in our study, so we could not quantify possible population-level effects of human disturbance in this small, declining population, but the potential for population-level effects exists. The lack of observed mating behaviors after human disturbance, in combination with known late arrivals and early departures by the public at viewing blinds, could reduce reproductive success if blinds receive regular use and mating is delayed (Baydack and Hein 1987).

The benefits obtained from viewing blinds to garner public support for prairie grouse conservation have also not been quantified. In our study, blind reservations had no cost, and we do not know if observers later bought small game licenses, donated to Nongame Wildlife Check Offs on state tax returns, or donated to other conservation programs. We do know that three of 40 people reserving blinds were members of the Minnesota Sharp-tailed Grouse Society, five people were active or retired professionals for the Department of Natural Resources, one was a bird guide, and two were reporters, which may have had fartherreaching impacts than attendance by other observers. We also know that children attended blinds on at least nine occasions and at least two teenagers visited. The impacts of these experiences on youth in terms of fostering future support for grouse conservation remain unknown and are difficult to quantify. At this juncture, with so many unknowns related to quantifying costs and benefits of viewing blinds in declining populations, efforts to minimize human disturbance on leks should be a priority.

Responses to this article can be read online at: https://www.ace-eco.org/issues/responses.php/1986

\section{Acknowledgments:}

We would like to thank the Minnesota Sharp-tailed Grouse Society and wildlife managers with the Minnesota Department of Natural Resources in the east-central Sharp-tailed Grouse region of Minnesota for identifying this information need. We would like to thank David Dragon, Joe Worm, Melissa Koelsch, Scott Laudenslager, and Derek Frost for setting up viewing blinds that could be reserved by the public, assisting with maintenance of cameras during lek visits, and adjusting blinds for public use. We would like to thank Jodie Provost, Derek Frost, Jessica Holmes, Martha Minchak, Joe Worm, Melissa Koelsch, and Chris Balzer for assisting with initial lek location. Our dedicated volunteers, Alex Elliott, Dan Ruka, Benjamin Bullard, and Joe Rohm, spent many mornings in blinds. John Giudice and Veronique St-Louis provided statistical advice on study design. Fleet costs for this study were funded by the Minnesota Department of Natural Resources. We would like to thank editor Hobson and two anonymous reviewers for their thoughtful and constructive reviews.

\section{LITERATURE CITED}

Baines, D., and M. Richardson. 2007. An experimental assessment of the potential effects of human disturbance on Black Grouse Tetrao tetrix in the North Pennines, England. Ibis 149 (s1):56-64. https://doi.org/10.1111/j.1474-919X.2007.00638.x

Baydack, R. K. 1986. Sharp-tailed Grouse response to lek disturbance in the Carberry Sand Hills of Manitoba. Dissertation, Colorado State University, Fort Collins, Colorado, USA.

Baydack, R. K., and D. A. Hein. 1987. Tolerance of Sharp-tailed Grouse to lek disturbance. Wildlife Society Bulletin 15:535-539. [online] URL: https://www.jstor.org/stable/3782577

Connelly, J. W., M. W. Gratson, and K. P. Reese. 2020. Sharptailed Grouse (Tympanuchus phasianellus), version 1.0. In A. F. Poole and F. B. Gill, editors. Birds of the world. Cornell Lab of Ornithology, Ithaca, New York, USA. https://doi.org/10.2173/ bow.shtgro.01 
Corace, R. G. III, S. A. Weiss, and L. M. Shartell. 2018. Volunteer observer bias and Sharp-tailed Grouse lek counts in the Upper Midwest. Journal of Fish and Wildlife Management 9:666-677. https://doi.org/10.3996/112017-JFWM-095

Cowles, S. A., and R. M. Gibson. 2015. Displaying to females may lower male foraging time and vigilance in a lekking bird. Auk 132:82-91. https://doi.org/10.1642/AUK-14-67.1

Drummer, T. D., R. G. Corace III, and S. J. Sjorgen. 2011. Sharptailed Grouse lek attendance and fidelity in Upper Michigan. Journal of Wildlife Management 75:311-318. https://doi. org/10.1002/jwmg.42

Flock, B. E., K. R. Van Why, and R. D. Applegate. 2002. Harassment of a Greater Prairie-Chicken lek by American Crows. Proceedings of the Oklahoma Academy of Science 82:1-3.

Gratson, M. W., G. K. Gratson, and A. T. Bergerud. 1991. Male dominance and copulation disruption do not explain variance in male mating success on Sharp-tailed Grouse (Tympanuchus phasianellus) leks. Behaviour 118:187-213. https://doi. org/10.1163/156853991X00283

Hanowski, J. M., D. P. Christian, and G. J. Niemi. 2000. Landscape requirements of prairie Sharp-tailed Grouse Tympanuchus phasianellus campestris in Minnesota, USA. Wildlife Biology 6:257-263. https://doi.org/10.2981/wlb.2000.024

Hanson, B. 2021. Wisconsin sharp-tailed grouse survey. Wisconsin Department of Natural Resources. Madison, Wisconsin, USA. https://widnr.widen.net/s/d27gnjdnrp/sharptailedgrousesurvey 2021

Hjorth, I. 1970. Reproductive behavior in Tetraonidae. Viltrevy 7:282-525.

Johnsgard, P. A. 2002. Grassland grouse and their conservation. Smithsonian Institution Press, Washington, DC, USA.

Kermott, L. H. III. 1982. Breeding behavior in the Sharp-tailed grouse. Dissertation, University of Minnesota, Minneapolis, Minnesota, USA.

Kuznetsova, A., P. B. Brockhoff, R. H. B. Christensen, and S. P. Jensen. 2020. Package 'ImerTest': tests in linear mixed effects models, version 3.1-3. [online] URL: https://cran.r-project.org/ web/packages/lmerTest/lmerTest.pdf

Landel, H. 1989. A study of female and male mating behavior and female mate choice in the Sharp-tailed Grouse, Tympanuchus phasianellus jamesi. Dissertation, Purdue University, West Lafayette, Indiana, USA.

Laursen, K., J. Kahlert, and J. Frikke. 2005. Factors affecting escape distances of staging waterbirds. Wildlife Biology 11:13-19. https://doi.org/10.2981/0909-6396(2005)11[13:FAEDOS]2.0.CO;2

Lehmann, V. W. 1941. Attwater's Prairie Chicken, its life history and management. North American Fauna 57, U.S. Fish and Wildlife Service, Washington, DC, U.S.A. https://doi. org/10.3996/nafa.57.0001

Luke, S. G. 2017. Evaluating significance in linear mixed-effects models in R. Behavioral Research 49(4):1494-1502. https://doi. org/10.3758/s13428-016-0809-y.
Maples, T. E., and G. J. Soulliere. 1996. Status of Michigan Sharptailed Grouse in the 1990's. Wildlife Division Report 3256, Michigan Department of Natural Resources, Lansing, Michigan, USA.

Miller, G. C., and W. D. Graul. 1980. Status of Sharp-tailed Grouse in North America. Pages 18-28 in P. A. Vohs and F. L. Knopf, editors. Proceedings of the Prairie Grouse Symposium. Oklahoma State University, Stillwater, Oklahoma, USA.

Oberbillig, D. R. 2011. A guide to wildlife viewing and photography blinds: creating facilities to connect people with nature. Colorado Division of Wildlife, Denver, Colorado, USA and Virginia Department of Game and Inland Fisheries, Richmond, Virginia, USA. [online] URL: https://donnallong. com/wp-content/uploads/2011/12/us-viewing-blinds-publicationlow-res.pdf

R Core Team. 2018. R: a language and environment for statistical computing. Statistical Computing, Vienna, Austria. [online] URL: https://www.R-project.org/

Robel, R. J. 1970. Possible role of behavior in regulating Greater Prairie-chicken populations. Journal of Wildlife Management 34:306-312. https://doi.org/10.2307/3799014

Roy, C. L. 2018. 2018 Minnesota spring grouse surveys. Forest Wildlife Populations and Research Group, Minnesota Department of Natural Resources. Grand Rapids, Minnesota, USA. [online] URL: https://files.dnr.state.mn.us/recreation/ hunting/grouse/grouse_survey_report18.pdf

Roy, C. L. 2019. 2019 Minnesota spring grouse surveys. Forest Wildlife Populations and Research Group, Minnesota Department of Natural Resources. Grand Rapids, Minnesota, USA. [online] URL: https://files.dnr.state.mn.us/recreation/ hunting/grouse/grouse_survey_report19.pdf

Roy, C. L. 2021. Minnesota sharp-tailed grouse survey. Forest Wildlife Populations and Research Group, Minnesota Department of Natural Resources. Grand Rapids, Minnesota, USA. [online] URL: https://files.dnr.state.mn.us/wildlife/grouse/ reports/sharptail/stail_survey_2021.pdf

Roy, C. L., and A. J. Gregory. 2019. Landscape and population genetics reveal long-distance Sharp-tailed Grouse (Tympanuchus phasianellus) movements and a recent bottleneck in Minnesota. Conservation Genetics 20:259-273. https://doi.org/10.1007/ s10592-018-1128-x

Sadoti, G., K. Johnson, and T. P. Albright. 2016. Modelling environmental and survey influences on lek attendance using long term lek survey data. Ibis 158:821-833. https://doi.org/10.1111/ ibi. 12391

Sexton, D. A. 1979. Off-lek copulation in Sharp-tailed Grouse. Wilson Bulletin 91:150-151. [online] URL: https://sora.unm.edu/ sites/default/files/journals/wilson/v091n01/p0150-p0151.pdf

Smit, C. J., and G. J. M. Visser. 1993. Effects of disturbance on shorebirds: a summary of existing knowledge from the Dutch Wadden Sea and Delta area. Wader Study Group Bulletin 68:6-19. [online] URL: https://sora.unm.edu/sites/default/files/journals/ iws/n005/p00006-p00019.pdf 
Sparling Jr., D. W., and W. D. Svedarsky. 1978. Responses of prairie grouse to avian and mammalian visitors on display grounds in northwestern Minnesota. Prairie Naturalist 10:17-22.

Stankowich, T., and D. T. Blumstein. 2005. Fear in animals: a meta-analysis and review of risk assessment. Proceedings of the Royal Society of London B: Biological Sciences 272:2627-2634. https://doi.org/10.1098/rspb.2005.3251

Storch, I. 2013. Human disturbance of grouse-why and when? Wildlife Biology 19:390-403. https://doi.org/10.2981/13-006

Thiel, D., E. Ménoni, J. Brenot, and L. Jenni. 2007. Effects of recreation and hunting on flushing distance of capercaillie. Journal of Wildlife Management 71:1784-1792. https://doi. org/10.2193/2006-268

Tsuji, L. J. S. 1992. Snowfall causes lek movement in the Sharptailed Grouse. Wilson Bulletin 104:188-189. [online] URL: http:// www.jstor.org/stable/4163133

Tsuji, L. J. S., D. R. Kozlovic, M. B. Sokolowski, and R. I. C. Hansell. 1994. Relationship of body size of male Sharp-tailed Grouse to location of individual territories on leks. Wilson Bulletin 106:329-337. [online] URL: https://www.jstor.org/ stable/4163423

Wiley, R. H. 1974. Evolution of social organization and life history patterns among grouse. Quarterly Review of Biology 49:201-227. https://doi.org/10.1086/408083

Ydenberg, R. C., and L. M. Dill. 1986. The economics of fleeing from predators. Advances in the Study of Behavior 16:229-249. https://doi.org/10.1016/S0065-3454(08)60192-8 